\title{
CONCRETE WITH HIGH CONTENT OF FLY-ASH FOR COMMON USE IN CONDITIONS OF THE CZECH REPUBLIC
}

\author{
Hana Š́chová ${ }^{1}$, Petr Huňka ${ }^{2}$ \\ ${ }^{1}$ Chryso chemie, s.r.o., Prague, Czech Republic \\ ${ }^{2}$ Klokner institute, Prague, Czech Republic
}

\begin{abstract}
HVFAC = High Volume Fly Ash Concrete where fly ash is used in excess of 40\% having better slump retention, better (lower) temperature of hydration and very cohesive mix. HVFAC is specially designed and final properties depend on combination of raw material, additives, admixtures and especially on quality of fly ash. Klokner Institute cooperates with Chryso Chemie Czech Republic on research programme focused on HVFAC in local conditions of Czech Republic, where main problem is that quality of fly ashes is not good. Article describes optimization process and evolution of admixtures for HVFAC. Basic material properties of fresh and harden concrete are presented (slump test, air content, compressive strength etc.)
\end{abstract}

Keywords: Fly ash, Concrete, Superplasticizer, and HVFAC

\section{INTRODUCTION}

Concrete with high substitute of the cement with fly-ash (FAC) is favourably used for structures with undesirable development of hydration heat or where reduction of the share of Portland clinker in the adhesive provides better resistance of concrete against impacts of acidic aggressive environment. Due to pozzolanic reaction flay-ash participates on formation of cement or adhesive stone and contributes to increased strength of concrete. As the pozzolanic reaction process is gradual its impact on the increased concrete strength is shown within longer time horizon (i.e. after lapse of standard age) and fly-ash concretes are therefore characterized by a short-term low strength which is one of its disadvantages mostly during winter season. However during summer season concretes with partial substitute of cement with fly-ash are beneficial solution for common use even from the aspect of reduced material costs on concrete production. Reduced cement volume in the concrete is nevertheless limited by requirements of ČSN EN 206-1 on concrete composition which is making difficult launch of concrete with higher cement substitutions with fly-ash on the Czech market. FAC allow effective use of the fly-ash, which is otherwise a waste product representing environmental load on spoil heaps as a substitute of clinker, the production of which is also environmentally loading from the power and raw materials aspect.

\section{SUPERPLASTIFICATION ADDITIVES FOR} CONCRETE WITH HIGH CONTENT OF

\section{FLY-ASH}

Substantial disadvantage of FAC is the low initial strength. In our developed fly-ash concrete these are formulations where minimum 30 weight percent was substituted with flyash. Most effective tool of strength increasing is reduction of water volume in the concrete. However, even with low water volume sufficient workability of fresh concrete must be secured, namely with use of additives which are among strongly water-reducing/superplastification additives according to ČSN EN 934-2. Most effective superplastification additives are those based on polycarboxylates. Chryso Chemie has available series of polymers based on polycarboxylates, which are produced in the production plant of the mother company in France. For the purpose of development of suitable superplastificators specially determined for FAC, all available polycarboxylate bases produced by Chryso were tested with use of internal testing method with selected cements and Czech fly-ashes and the most suitable bases were selected based on the test results, from which several new formulation of superplastificators were proposed. By suitable combination of selected bases can be purposefully affected adsorption behaviour of proposed formula of superplastificator, which has decisive effect on dispersion effect of the additive. Adsorption speed for specific combination of fly-ash, cement and polycarboxylate base was experimentally determined with use of TOC (Total Organic Carbon) analysis. For selection of most suitable bases for proposal of formulation of superplastification additive for FAC was also considered the economical view and the aim to find compromising solution between efficiency of the additive and its price. Further the contribution of additive of defoaming ingredient was monitored during the development of superplastification additive and its possible optimum dose. Effectiveness of such developed superplastificators and their impact on characteristics of fresh and compacted cement black mortars and mostly concretes was verified within laboratory and subsequently operational tests in the concrete plant. Even determination of dynamic viscosity of the actual superplastification additive under various temperatures was not omitted as it is important mainly for securing of easy dosing in concrete plants. In tables $\mathbf{1 , 2}$ and 
on the figure $\mathbf{1}$ are compared characteristics of both new developed superplastification additives for FAC.

Table 1: Mutual comparison of characteristics of new outlined superplastification additives for FAC

\begin{tabular}{|l|l|l|}
\hline Superplastificator ChrysoFluid $®$ & Optima 316 EMx & Optima 318 EMx \\
\hline Common proportioning (\% of adhesive weight) & $0,6-1,1$ & $0,6-0,9$ \\
\hline $\begin{array}{l}\text { Effective batch for the same concrete consistency (\% of } \\
\text { weight of bonding agent) }\end{array}$ & 0,90 & 0,75 \\
\hline Decrease of consistency of fresh concrete in time & higher & lower \\
\hline Inclination to concrete aeration & higher & lower \\
\hline Inclination to segregation & comparable & comparable \\
\hline Concrete movability ("non-adhesiveness") & honey-like & less honey-like \\
\hline Initial strengths $\leq 28 \mathrm{~d}$ (with the same water volume) & higher & lower \\
\hline Dry matter content according to ČSN 480-8 (\%) & $25-27$ & $25-27$ \\
\hline Density (kg/l) at $20^{\circ} \mathrm{C}$ & 1,06 & 1,06 \\
\hline pH & 8,2 & 7,7 \\
\hline Dynamic viscosity $\mathrm{mPa} . \mathrm{s}$ at $20^{\circ} \mathrm{C}$ & 99,1 & 56,7 \\
\hline
\end{tabular}

\section{ASSESSMENT OF SUITABILITY OF THE}

\section{FLY-ASH SELECTION FOR FAC}

Fly-ash for the concrete must comply with requirements of ČSN EN 450-1 (dated 02/2013). Within these requirements the monitored characteristics of the fly-ash from one producer may vary depending on the actual quality of burned coal, type of boiler and possibly on changes in the technology of fly-ash modification prior to its use in concrete. The extent, in which would this characteristics and fly-ash composition variability affect characteristics of fresh and compacted concrete depends indisputably on amount of fly-ash added to the concrete. It is obvious that FAC would react to changes in fly-ash characteristics more sensitively than the commonly used concrete with fly-ash in compliance with CัSN EN 206-1, where the cement substitutes with fly-ash usually oscillate around $10 \%$ of weight.

Therefore it is essential for FAC production to proceed carefully with selection of the actual fly-ash and make sure (ideally with contractual support) that the fly-ash comes always from the same producer. Successfulness in reaching the highest possible strengths of concrete with high ratio of fly-ash substitutions of cement depends very much on quality of selected fly-ash. We had a possibility to perform comparison of commonly used fly-ashes from the Czech Republic and sorted fly-ash from South Africa and it came out from the results that the South African fly-ash with higher fineness improved rather remarkably rheological behaviour of fresh concrete and strengths than untreated Czech fly-ashes. Besides the purposeful treatment also reduced variability of monitored physical characteristics of the fly-ash. But sorted fly-ash usually does not appear on the Czech market.

For the purpose of regular monitoring of flay-ash quality at the concrete producer or during searching and verification of suitability of new sources of the fly-ash it appears very beneficial to determine nominal weight, specific surface
(Blaine), remains on the mesh $0,045 \mathrm{~mm}$ and performance of the water-demand test according to ČSN EN 450-1 (enclosure

B) on mortars, the best in combination with used cement. The lower is value of water demand and higher the nominal weight of the fly-ash, the better is its impact on liquidity of fresh concrete and therefore its ability to contribute actively to overall reduction of water amount in the concrete. The best characteristics among tested Czech fly-ashes for FAC for the project proved the fly-ash from Dětmarovice power plant.

\section{PRINCIPLES FOR PROPOSAL OF CONTENT OF FAC}

Concretes with high ratio of fly-ash, mainly for strength classes C 20/25 and higher are more viscose compared to common concrete due to low content of gauge water. Basic assumption for successful proposal of FAC formulation is suitable composition of gravel aggregate with as lowest voids as possible. As followed from results of our tests, it is necessary for FAC compared to common concrete in order to reach good workability of fresh concrete volume of bonding cement must be increased. Apart from increased volume of bonding cement also water content must be optimised from the aspect of workability (to determine not only the upper level in order to reach required strengths but also minimum necessary volume of water to reach good movability of concrete), overall content of cement and flyash. In order to restrain adhesiveness of FAC the content of fly-ash should be limited by upper limit as well as overall content of cement as its excessive amount requires increased water dosing and superplastification additive and proves rather negatively on fresh concrete behaviour.

During production of fly-ash concrete in the concrete plant, where the concrete consistency is controlled by consistency meter working on the principle of monitoring of the mixer engine load, it must be considered that due to higher 
viscosity of FAC, higher values are demonstrated by the consistency meter (assessed for example by the setting test according to ČSN EN 12350-2), compared to results of common concretes of the same strength class, i.e. the concrete seems more dense. There is therefore relatively high risk of water overdosing with negative impact on concrete strengths, if the operating staff does not consider this fact. FAC are more sensitive to fluctuation of material characteristics of all compounds in concrete than common concretes, mainly to humidity of gravel aggregate. From the view of technologist, FAC are similarly demanding for production as are aerated concretes, self-compacting or high-strength concretes.

One of main tasks of superplastification additives specially developed for FAC is to allow reaching of de-moulding strengths of concrete during the time usual for common concrete of the same strength class at the temperature $20^{\circ} \mathrm{C}$. Significant argument against use of FAC is the slow increase of strengths at low temperatures due to low cement content. This fact still applies and use of FAC is less suitable during the winter season. It also followed from our experimental tests that suitable measure against impact of low temperatures is use of reasonably batched accelerating additive which would secure similar growth of strength in the initial hydration phase as have concretes without fly-ash. Another recommended measure for the winter season is also reduction of the cement substitution with fly-ash.

\section{COMPARISON OF CHARACTERISTICS OF FAC AND COMMON CONCRETE}

During laboratory tests was checked series of formulations FAC with various batches of cement and these were compared with common concretes according to ČSN EN 206-1 containing both the superplastification admixture on the base of polycarboxylates (Chryso Fluid Optima 224), and the economically useful plastification additive on the base of lignosulfonates (Plast 460). Results shown on the graph of fig. 1 document how the savings of cement can be reached with use of FAC for required compression strengths of concrete. Table tab. 2 shows selection of formulations of FAC and comparative common concretes from the graph on fig. 1, including measured consistency of fresh concrete and volume mass after 28 days.

Superplastificator Chryso Fluid Optima 316 EMx, developed for FAC, allows with very similar water volume in combination with used cement production of concrete of higher strength class than in case of use of superplastificator Chryso Fluid Optima 318 EMx. Advantage of superplastificator Chryso Fluid Optima 318 EMx is however its higher plastification effect compared to Optima 316 EMx and lower viscosity of fresh concrete.

It follows from comparison of obtained strengths of common concrete and FAC that the strength class C 25/30 can be reached with $300 \mathrm{~kg}$ of cement in combination with superplastificator Chryso Fluid Optima 224, or with use of formulation FAC with superplastificator Chryso Fluid
Optima 316 EMx, with $210 \mathrm{~kg}$ of cement and $150 \mathrm{~kg}$ of flyash. Consistency level of fresh concrete in both cases is S4, strength growth is slower in FAC but yet it allows comfortable de-moulding at the temperature $20{ }^{\circ} \mathrm{C}$ during the same time as the common concrete.

Reference concrete with plastification additive Chryso Plast 460 in the formulation without fly-ash had after 28 days strength of $34,2 \mathrm{MPa}$, in the formulation with reduced content of cement and added fly-ash in the quantity complying with ČSN EN 206-1/Z4 for XC1, XC2 reached standard strengths of $32,7 \mathrm{MPa}$. These strengths allow classification of both reference concretes with large reserve in the strength class C 20/25 (after 28 days). The same strength class is reachable even with FAC, in case of use of the superplastificator Chryso Fluid Optima 316 EMx, the sufficient amount of cement is $190 \mathrm{~kg}$, with superplastificator Chryso Fluid Optima 318 EMx then 210 $\mathrm{kg}$ cement in $1 \mathrm{~m}^{3}$ of concrete (see tab. 2).

\subsection{Working Verification Tests}

During working tests of concrete in the concrete plant were among others produced many testing bodies in order to allow performance of these additional tests:

- Development of temperatures of concrete during initial hydration of cement $(0-11$ days $)$ according to internal methodology of Klokner Institute in cubic mould with volume $27 \mathrm{dm}^{3}$

- Determination of volume changes of concrete (shrinkage) according to ČSN 731320

- Determination of concrete resistance against penetration of water under pressure accor. to ČSN EN 12390-8

- Determination of static compression modulus of elasticity according to ČSN ISO 6784

- Determination of resistance against carbonatation accelerated method, procedure according to ČSN EN 13295

Table tab. 3 shows on the example of two concretes comparison of characteristics of FAC produced with use of superplastificator ChrysoFluid Optima 316 EMx and traditional concrete according to ČSN EN 206-1 with superplastificator Chryso Fluid Optima 224; both concretes comply with the same strength class C 20/25 after 28 days.

One of the main tasks for specially developed superplastification additives for FAC was an effort to obtain de-moulding strengths during the time which is usual for common concrete for given strength classes and temperature $20{ }^{\circ} \mathrm{C}$ and allow assessment of strength classes within the standard age of concrete. If we decide to evaluate strength of concretes with high content of fly-ash in the age more than 28 days, the strength of FAC produced under comparable conditions are always higher than strengths of common concrete designed for the same standard strength class. If the required strength class is reached in the standard 
age "without reserve", then concretes with high content of fly-ash provide security that in the age of 56 days their strengths would fully comply with prescribed strength class. Potential of the growth of long-term strength of FAC is one of their big advantages.
Results of tests of resistance against pressure water impact on all tested formulations of concretes including FAC showed that maximum ingress did not exceed the value of $35 \mathrm{~mm}$.

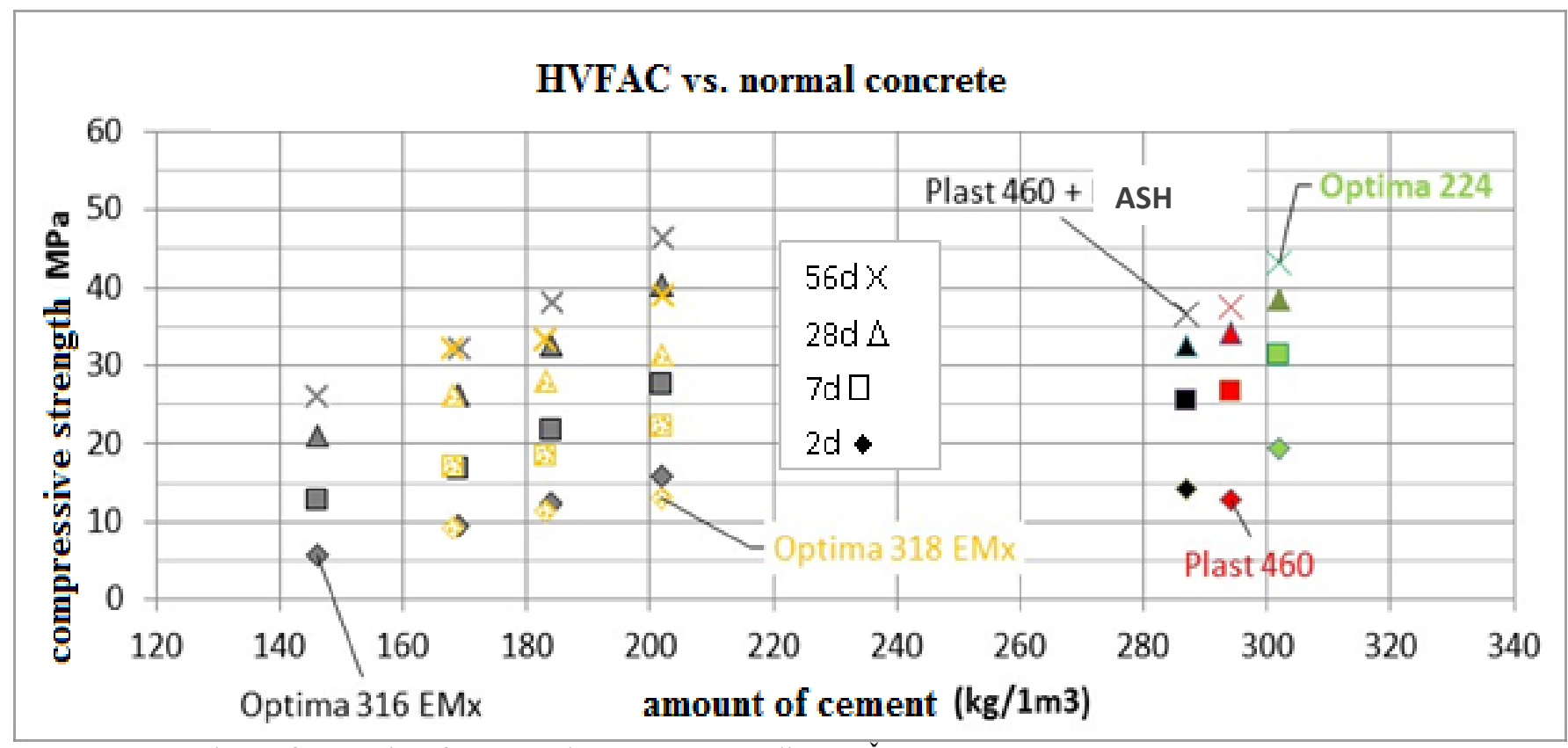

Fig. 1: Comparison of strengths of FAC and concretes according to ČSN EN 206-1 depending on batch of cement and age of concrete

Table 2: Selection for formulations FAC and common concrete from the graph on pic. 1

\begin{tabular}{|l|l|l|l|l|l|l|l|}
\hline & \multicolumn{6}{|l|}{ Concrete according to EN 206-1 } & FAC \\
\hline Admixtures & & Optima & Plast 460 & Plast 460 & Optima & Optima & Optima \\
\hline Batch & $\mathrm{kg}$ & 2,61 & 2,40 & 2,28 & 2,80 & 3,82 & 3,13 \\
\hline Cement & $\mathrm{kg}$ & 300 & 300 & 248 & 190 & 210 & 210 \\
\hline Fly-ash & $\mathrm{kg}$ & 0 & 0 & 60 & 140 & 150 & 150 \\
\hline Water & $\mathrm{kg}$ & 167 & 178 & 177 & 157 & 149 & 152 \\
\hline Setting & $\mathrm{mm}$ & 170 & 195 & 160 & 205 & 185 & 235 \\
\hline Bulk density & $\mathrm{kg} / \mathrm{m}^{3}$ & 2380 & 2370 & 2340 & 2330 & 2340 & 2310 \\
\hline Compression strength & $\mathrm{MPa}$ & 19,3 & 12,8 & 14,2 & 12,4 & 15,8 & 12,9 \\
\hline 2 days & $\mathrm{MPa}$ & 31,3 & 26,8 & 25,5 & 21,8 & 27,7 & 22,2 \\
\hline 7 days & $\mathrm{MPa}$ & $\mathbf{3 8 , 6}$ & $\mathbf{3 4 , 2}$ & $\mathbf{3 2 , 7}$ & $\mathbf{3 2 , 5}$ & $\mathbf{4 0 , 4}$ & $\mathbf{3 1 , 4}$ \\
\hline 28 days & $\mathrm{MPa}$ & 43,3 & 37,6 & 36,7 & 38,2 & 46,3 & 39,1 \\
\hline 56 days &
\end{tabular}

Table 3: Comparison of characteristics and composition of selected FAC and traditional concrete produced within working tests.

\begin{tabular}{|l|l|l|l|}
\hline Concrete & & FAC & As per EN 206-1 \\
\hline Superplastificator Chryso Fluid & & Optima 316 EMx & Optima 224 \\
\hline Batch of additive & $\mathrm{kg}$ & 3,24 & 2,90 \\
\hline Cement CEM II/A-LL 42,5 R & $\mathrm{kg}$ & 210 & 300 \\
\hline Fly-ash & $\mathrm{kg}$ & 150 & 0 \\
\hline Gravel aggregate in total & $\mathrm{kg}$ & 1821 & 1865 \\
\hline Water & $\mathrm{kg}$ & 149 & 174 \\
\hline Consistency of fresh concrete - setting & $\mathrm{mm}$ & 265 & 220 \\
\hline
\end{tabular}




\begin{tabular}{|l|l|l|l|l|}
\hline Air content in fresh concrete & $\%$ vol. & 2,0 & 1,7 \\
\hline Bulk density during 28 days & $\mathrm{kg} / \mathrm{m}^{3}$ & 2330 & 2310 \\
\hline Compression strength & 1 day & $\mathrm{MPa}$ & 8,0 & 12,2 \\
\hline & 7 days & $\mathrm{MPa}$ & 19,5 & 21,5 \\
\hline & 28 days & $\mathrm{MPa}$ & 29,6 & 28,2 \\
\hline & 56 days & $\mathrm{MPa}$ & 36,0 & 33,7 \\
\hline Depth of penetration of water under presser & $\mathrm{mm}$ & 17 & 19 \\
\hline Carbonatation depth & $\mathrm{mm}$ & 3,0 & 2,0 \\
\hline Shrinkage after 91 days & $\mathrm{mm} / \mathrm{m}$ & $-0,519$ & $-0,520$ \\
\hline Static modulus of elasticity - beam & $\mathrm{GPa}$ & 25,3 & 25,0 \\
\hline Maximum temperature during hydration $/$ for the & ${ }^{\circ} \mathrm{C} / h$ & $40,2 / 30,5$ & $48,0 / 22,0$ \\
\hline Price (bonding agent $\square$ additive) & $\mathrm{ZCK} / \mathrm{m}^{3}$ & $\mathrm{X}-16 \%$ & $\mathrm{X}$ \\
\hline
\end{tabular}

Concretes with high substitution of cement with fly-ash are often discussed from the view of their resistance against carbonatation. Fly-ash is an additive with pozzolan characteristics and its siliceous compounds react with the portlandite originating during cement hydration under generation of phases C-S-H. During this reaction, similarly to carbonatation, is consumed calcium hydroxide (portlandite) and this leads to decrease of concrete $\mathrm{pH}$. Low content of clinker in FAC is nevertheless compensated by optimisation of the formulation namely by significant reduction of gauge water due to reached required strength and thanks to progressing pozzolanic reaction the porous structure of these concretes is more dense which has positive impact against progress of carbonatation. It is stated in [1] that up to the amount of $60 \%$ of weight of flyash content there is no risk of critical reduction of $\mathrm{pH}$ of porous concrete solution. Our results proved that resistance against carbonatation of FAC and traditional concretes are very similar, in case of comparison of absolute values it may seem worse for FAC, however absolute measured values are very low and differences vary in the scope of uncertainty of measuring.

Measured values of static elasticity modulus are relatively low in relation to values considered by Eurocode 2, for both FAC and comparative common concrete. Between both concretes are minimum differences in modulus value. Low modulus of elasticity of concrete probably related to changes of composition of concrete during last $20-30$ years and most probably to petrographic origin of used coarse gravel aggregate [2].

Concrete with high content of fly-ash does not represent risk even from the view of volume changes (shrinkage), in comparable strength classes FAC have comparable or even lower shrinkage than traditional concrete, thanks to lower amount of cement and gauge water in the formulation.

Big advantage of FAC is their use in structures requiring low and slow development of hydration heat without need of use of special LH - cement. Measurements performed on all tested concrete formulations proved that the most significant factor influencing development of temperatures during hydration is the cement content. Difference in maximum obtained temperature between FAC and common concrete without fly-ash was remarkable and was almost 8 ${ }^{\circ} \mathrm{C}$ in the core of test body, start of maximum temperature was also slower in FAC (see tab. 3). As a matter of interest, difference in the maximum obtained temperature between traditional concretes with Optima 224 (without fly-ash, with $300 \mathrm{~kg}$ of cement) and concrete with Plast 460 (with $248 \mathrm{~kg}$ of cement and $60 \mathrm{~kg}$ of fly-ash), the composition of which is in detail shown in tab. 2 , was only $2{ }^{\circ} \mathrm{C}$.

FAC represent positively more advantageous economical solution in comparison with common concretes. As the structure of sold concrete and structure of material costs varies only according to producers, we cannot make exact calculation of economical impact of launching of FAC into production. Highest material savings on our developed formulations of FAC can be reached in concretes for the class C 20/25, usual savings for use of FAC should vary most often between 5 and $10 \%$ of all material costs.

\section{PROBLEMS OF LAUNCHING FAC ON THE CZECH REPUBLIC MARKET}

Harmonized standard ČSN EN 206-1 exists for transport concrete, defining requirements on concrete characteristics emphasizing its quality and lifetime. This implies that the environment where the concrete would be used is often the decisive criteria for its selection. Concrete with higher content of fly-ash usually does not comply with all requirements of this standard and would be therefore unusable for constructions.

Building products for which there is no harmonized standard are in the Czech Republic evaluated according to Decree of the government No. 163/2002 Coll., stating technical requirements on selected building products, as amended by the Decree of the government No. 312/2005 Sb. (NV 163). Process of compliance assessment is using so called determined standards and system of construction and technical certificates. 
To make use of FAC practically feasible, we proposed for the selected pilot case a method of approval through application for issue of construction and technical certificate by an Authorized Body. The application was documented by corporate standard using content of $\mathrm{k}$-value with values determined according to articles 5.2.5.1, 5.2.5.2 and 5.2.5.3 of CSN EN 206-1 and stated in the enclosure A, always for the nominal combination cement + fly-ash + additive. Kvalue is always determined and confirmed on the basis of comparative tests between common concrete fully in accordance with ČSN EN 206-1/Z4 and concrete FAC with selected combination of the same cement, fly-ash and admixture.

During production of concrete according to this corporate standard were performed probative tests according to ČSN EN 206/1/Z4. For evidence of concrete durability according to article 5.2.5.3 of ČSN EN 206-1/Z3, with use of k-values determined according to corporate standard would be made extra test of concrete resistance against carbonatation according to ČSN EN 13295 and test of depth of penetration of water under pressure according to ČSN EN 12390-8.

\section{CONCLUSION}

Use of concretes with high content of fly-ash in practice is preceded no only by difficult process of approving but series of probative tests of concrete formulations based on careful selection of suitable raw materials, specifically designed superplastification additives and observation of certain principles for design of concrete composition. While common concretes according to ČSN EN 206-1 contain substitution of cement with fly-ash on the level of about 10 $\%$ of weight, the our proposed concept of FAC allows obtaining of substitution higher than $30 \%$ of weight with the same standard strength class of concrete, allowing comfortable de-moulding and equal or even better physical and mechanical parameters (long-term strengths, volume changes, development of hydration heat) and parameters of durability (resistance against carbonatation, watertightness). Also their economical and environmental contribution is indisputable.

Presented results are part of the solution of program project TIP announced by Ministry of Industry and Trade of the Czech Republic and registered under No. FR-TI3/747.

\section{REFERENCES}

[1] Meng, B.; Wiens, U.: Wirkung von pozzolanen bei extrem hohen Dosierung - Grenzen der Anwendbarkeit. In 13. Internat. Baustofftagung IBAUSIL 1997, Weimar, s. 1.0175-1.0186

[2] Huňka, P.; Kolísko, J.; Kolář, K.: Porovnání výsledků statického modulu pružnosti v tlaku různých receptur $\mathrm{s}$ hodnotami uvedenými $\mathrm{v}$ ČSN 1992-1-1. BETON TKS, 2013, č.6, s. 53-55. ISSN 1213-3116 (Comparison of results of static elasticity modulus in compression in various formulations with values stated by $C S N$ )

\section{BIOGRAPHIES}

Ing. Hana Š́ahová, Ph.D., has received the Ph.D. degree from the Brno University of Technology, Faculty of Civil Engieering, Czech Repubic. Currently working as head of laboratory of building materials in Chryso chemie s.r.o.

Ing. Petr Huňka, Ph.D., has received his masters from the Brno University of Technology, Faculty of Civil Engieering and Ph.D. degree from the Czech Technical University in Prague, Faculty of Civil Engieering Czech Repubic. Currently working as scientific worker and $\mathrm{Ph} . \mathrm{D}$. in the experimental department of Klokner institute, Prague. His research interests are in the field of technology of concrete and testing of its properties. 